\title{
Environmental Contaminants and the Prevalence of Hemic Neoplasia (Leukemia) in the Common Mussel (Mytilus edulis Complex) from Puget Sound, Washington, U.S.A.
}

\author{
P. K. Krishnakumar,* E. Casillas, R. G. Snider, A. N. Kagley, and U. Varanasi \\ Environmental Conservation Division, Northwest Fisheries ScienceCenter, National MarineFisheries Service, National Oceanic and \\ Atmospheric Administration, 2725 MontlakeBoulevard East, Seattle, Washington 98112-2097, U.S.A.; and *Research Centre, \\ Central MarineFisheries Research Institute, PB No. 244, Bolar, Mangalore 575 001, India
}

Received F ebruary 17, 1998; accepted J une 11, 1998

The relationship between hemic neoplasia, a blood cell disorder in bivalve molluscs, and chemical contaminants was evaluated in the common mussel (Mytilus edulis complex). Hemic neoplasia (HN) is endemic to mussel populations in Puget Sound. The prevalence of hemic neoplasia ranged from 0 to $30 \%$ in mussels from nine sites in Puget Sound, Washington. Organic chemical contamination in sediment from these sites range from 0.1 to $64.0 \mathrm{ppm}$ of polycyclic aromatic hydrocarbons (PAHs) and 0.07 to $0.50 \mathrm{ppm}$ chlorinated hydrocarbons. No relationship between the body burden of environmental contaminants and the prevalence of HN in mussels was identified. To evaluate the shortterm ability of chemical contaminants to induce $\mathrm{HN}$ in mussels, mussels, from a site where mussels were previously determined to be $\mathrm{HN}$ free, were fed microencapsulated PAHs (composed of a mixture of phenanthrene, flouranthene, and benzo[a]pyrene) or PCBs (Aroclor 1254) and the prevalence of HN was assessed after 30 days of exposure. Although an apparent increase in $\mathrm{HN}$ prevalence ( 20 to $30 \%$ ) was observed in all treatments groups except the untreated controls, no significant difference in the prevalence of $\mathrm{HN}$ was observed between the control group of mussels fed corn oil (vehicle) and mussels fed either PAHs or PCBs in corn oil. A long-term (180-day) exposure study was conducted to evaluate the influence of PAHs or PCBs in modulating the prevalence of $\mathrm{HN}$ in a mussel population already exhibiting a moderate HN prevalence. Mussels, from a site where mussels were previously determined to exhibit a background prevalence of $\mathrm{HN}$, fed microencapsulated PAHs, PCBs, and corn oil (vehicle) over a long time period (180 days), revealed an apparent increased prevalence of HN (30 to 40\%) above the low levels (20\%) initially present. However, no significant difference in the prevalence of $\mathrm{HN}$ was observed between the control group of mussels fed corn oil (vehicle) and mussels fed either PAHs or PCBs in corn oil. Although chemical contami nants have been proposed as a modulating factor in the development and promotion of $\mathrm{HN}$ in bivalve molluscs from environmentally stressed and degraded habitats, we find no evidence that chemical contaminants induce or promote the development of $\mathrm{HN}$ in the mussel $\mathrm{M}$. edulis complex. 1999Academic Press

Key Words: Mytil us eduli is; hemic neoplasia; microencapsulated contaminants; PAHs; Aroclor 1254; PCBs.

\section{INTRODUCTION}

The major neoplasm reported in bivalves and presumed to be of blood cell origin has variously been designated sarcoma, hematopoi etic neoplasm, disseminated neoplasia, hemic neoplasia, leukemia, or blood cell proliferative disorder. Neoplastic conditions have been reported worldwide in 15 species of bivalves, including 4 species of oysters, 6 species of clams, and 5 species of mussels (see review by Elston et al., 1992). The disease is characterized by proliferation of enlarged circulating hemocytes with a largel obatenucleus, one or more nucleoli, a high frequency of mitotic figures, and a high nucleus to cytoplasm ratio (F arley, 1969; Mix, 1983). The etiology of molluscan neoplasia remains uncertain, and several researchers have suggested possiblecauses ranging from carcinogenic chemicals (Lowe and Moore, 1978; Farley et al., 1991), to involvement of a c-type retrovirus (Oprandy et al., 1981; Elston et al., 1988), to genetic disposition of individuals (Couch and Harshbarger, 1985).

A chemical etiology has been suggested as a principle factor in the development of this neoplastic disorder. For example, Lowe and Moore (1978), while investigating hemic neoplasia ( $\mathrm{HN})$ in the common mussel, Mytilus edulis, demonstrated the presence of domestic and industrial pollution, including hydrocarbons, at a 
site in England where the mussels exhibited a high prevalence of this type of disease. Environmental contaminants, such as hydrocarbons, were suspected to be the causative factor for $\mathrm{HN}$ in clams collected from oil spill sites in Searsport, Maine (Barry and Yevich, 1975), and Freeport, Maine (Yevich and BarcszC, 1977). Similarly, Balouet et al. (1986) noticed an increased incidence of $\mathrm{HN}$ in oysters from areas affected by the Amoco Cadiz oil spill in France. I n addition, White et al . (1993) documented the high continued prevalence of $\mathrm{HN}$ in the softshell clam, Mya arenaria, associated with an industrially contaminated site at New Bedford Harbor, Massachusetts.

Attempts to define the linkages between exposure to chemical contaminants and development of $\mathrm{HN}$ have produced mixed results. A recent study by Farley et al. (1991) in the softshell clam M. arenaria from Chesapeake Bay reported a linear correlation between prevalence of the disease and tissue concentration of chlordane. In contrast, detailed investigations by Mix and Schaffer (1983) on HN in M. edulis from Yaquina Bay, Oregon, could not reveal a direct causal relationship between polynuclear aromatic hydrocarbon (PAH) exposure and the incidence of neoplasia. Evidence from laboratory studies lends some support to chemical causes for certain experimentally induced molluscan neoplasms (Khudoley and Syrenko, 1978). Winstead and Couch (1988) noted suspicious lesions induced in oysters exposed to both PAHs and diethylnitrosamine. In contrast, Rasmussen et al. (1983a,b, 1985) were unsuccessful in inducing neoplasia in $M$. edulis by repeated experimental injection with various organic contaminants.

In our field study using wild populations of mussels from Puget Sound, Washington significant correlations were observed between body burdens of organic contaminants and significant biological effects, including impaired lysosomal functions and induction of detoxifying and antioxidant enzymes (Krishnakumar et al., 1994, 1995). Mussels from Puget Sound, Washington, reportedly have a high prevalence of HN (Elston et al., 1988; Moore et al., 1991). However, very few studies have reported the relationship, if any, between the prevalence of hemic neoplasia in field populations of bivalves and the body burdens of environmental contaminants. Accordingly, in the present study we have addressed this relationship by (1) evaluating the prevalence of HN in M. edul is collected from various sites in Puget Sound and body burdens of environmental contaminants and (2) determining under laboratory exposure whether selected PAHs or PCBs induce or modulate the expression of $\mathrm{HN}$ in M. edulis. These studies were designed to clarify the relationship between chemical contaminants and the induction and/or proliferation of $\mathrm{HN}$ in bivalve populations.

\section{MATERIAL AND METHODS}

\section{Field Survey}

Mussels (M. edulis complex), 45-55 mm, were collected from their natural beds at nine sites in Puget Sound, Washington, during low tide (Fig. 1). Digestive gland tissue samples for histological analysis of $\mathrm{HN}$ were from mussels used previously in a companion study from nine sites in Puget Sound sampled during September 21-24, 1992 (seeK rishnakumar et al., 1994). On J anuary 9-February 7, 1993, mussels were again sampled to conduct a hemocytological assessment of $\mathrm{HN}$ in the natural populations and to confirm findings derived from the previous histological assessment.

Sites included the nonurban areas of Oak Bay, Coupeville, and Double Bluff in central and northern Puget Sound and Saltwater State Park in southern Puget Sound. Urban sites sampled included Eagle Harbor, Seacrest, and Four Mile Rock in Elliott Bay, City Waterway in Commencement Bay, and Sinclair Inlet, located near Bremerton (Fig. 1). Mussels from urban areas were known to be chronically exposed to a variety of anthropogenic chemical contaminants including PAHs, PCBs, and toxic metals (Krishnakumar et al., 1994).

Mussels used for the study were transported in

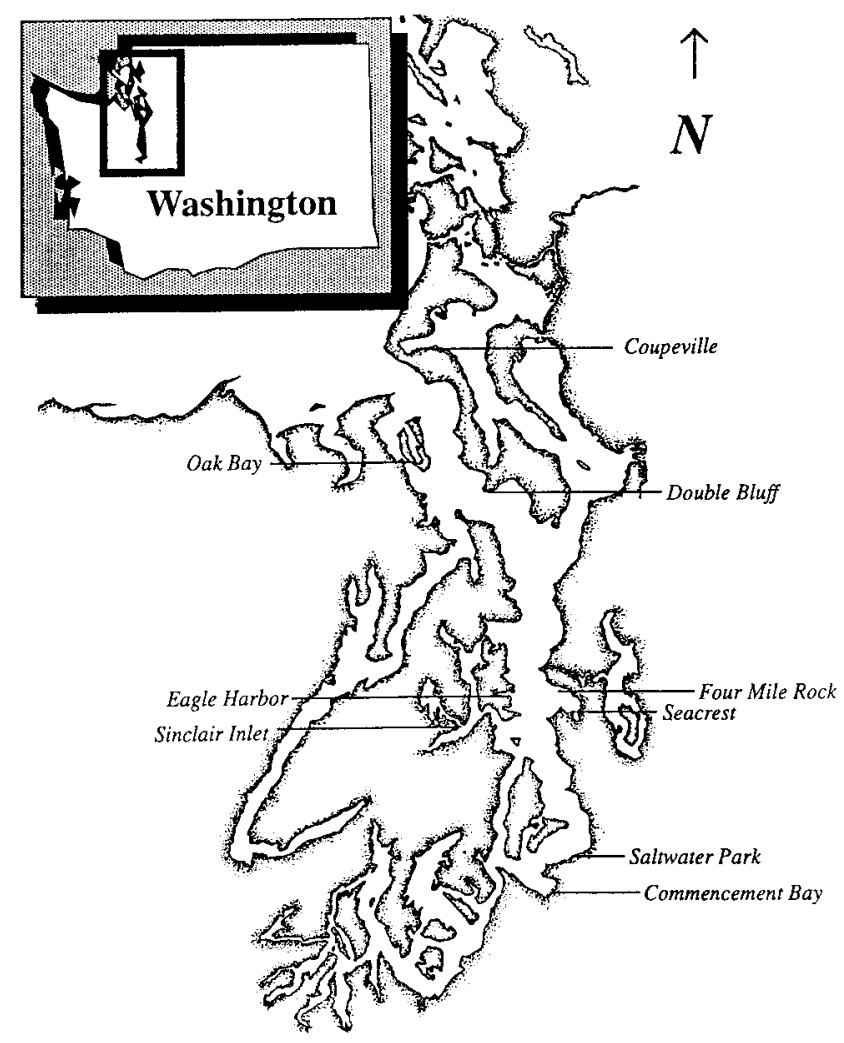

FIG. 1. Map of collection sites in Puget Sound, Washington. 
ambient seawater-filled ice chests to the National Marine Fisheries Service field Iaboratory at Mukilteo, Washington, immediately placed in circular seawater tanks, and acclimated for a period of $24 \mathrm{~h}$ to allow the guts to be cleared before they were randomly subsampled for chemical and histological analysis. Mussels for hemocytological analysis were maintained in unfiltered, running seawater during the 5-6 days required for the examination.

\section{Microencapsulation of Contaminants}

Selected PAHs or PCBs were microencapsulated in a gelatin/acacia gum mixture as described by Stromgren et al. (1986). Known amounts of PAHs or PCBs (as aroclor 1254) were dissolved in $20 \mathrm{~mL}$ corn oil, heated to $40^{\circ} \mathrm{C}$, and sonicated for $20 \mathrm{~min}$. This mixture was homogenized with $5 \mathrm{~g}$ of acacia gum and $5 \mathrm{~g}$ of gelatin in a blender for $2 \mathrm{~min}$ at $40^{\circ} \mathrm{C}$ and brought to a final volume of $1 \mathrm{~L}$ with $40^{\circ} \mathrm{C}$ deionized water. The emulsion was cooled for $1 \mathrm{~h}$ on ice to form hardened microencapsulated vessels and stored in a refrigerator in sealed containers. The vehicle control, $20 \mathrm{~mL}$ of corn oil, was also microencapsulated as described above. This procedure reportedly gives microcapsules with a diameter of 1-10 $\mu \mathrm{m}$, with most of the capsules around $5 \mu \mathrm{m}$, and stable with respect to particle dispersion and size (Stromgren et al., 1986).

\section{Short-Term Exposure(30 Days)}

Mussels (50-60 mm) were collected from a neoplasiafree and apparently healthy population from the minimally contaminated, nonurban site at Double Bluff (based on the results of the field survey) during low tide. The weight of PAHs used to make contaminantladened vesicles included $85.5 \mathrm{mg}$ of phenanthrene, $68.4 \mathrm{mg}$ of fluoranthene, and $17.1 \mathrm{mg}$ of benzo[a]pyrene (ratio 5:4:1, w:w:w) dissolved in $20 \mathrm{~mL}$ of corn oil and microencapsulated as described above. Similarly, 171 $\mathrm{mg}$ of PCBs (as Aroclor 1254) was dissolved in $20 \mathrm{~mL}$ of corn oil and microencapsulated as described above. The 1-L emulsion contained $171 \mathrm{mg}$ of PAHs or PCBs. Proportionate amounts of microencapsulated PAHs, PCBs, or corn oil were added daily to the respective tanks to achieve an equivalent final concentration of $150 \mu \mathrm{g}$ contaminant $\mathrm{L}^{-1}$ seawater. Hemocytological and histological examinations were made following shortterm exposure (all treatments).

\section{Long-Term Exposure (180 Days)}

For this study, mussel populations al ready exhibiting a moderate prevalence of $\mathrm{HN}$ were collected from a minimally contaminated nonurban site at Coupeville. The weight of PAHs used to make contaminant-laden vesicles for this portion of the study included $19 \mathrm{mg}$ phenanthrene, $15.2 \mathrm{mg}$ fluoranthene, and $3.8 \mathrm{mg}$ benzo[a]pyrene (ratio 5:4:1, w:w:w) dissolved in $20 \mathrm{~mL}$ of corn oil and microencapsulated. Similarly, $38 \mathrm{mg}$ of PCBs (as Aroclor 1254) was dissolved in $20 \mathrm{ml}$ of corn oil and microencapsulated. The 1-L emulsion contained $38 \mathrm{mg}$ of PAHs or PCBs. The microencapsulated PAHs, PCBs, or corn oil were added to the respective tanks on alternate days to achieve an equivalent final concentration of $10 \mu \mathrm{g}$ contaminant $\mathrm{L}^{-1}$ seawater. Hemocytological examinations were made following long-term exposures (all treatments).

\section{ExposureSetup}

Mussels were cleaned and acclimated for 1 week prior to the study in unfiltered running seawater containing natural phytoplankton with an ambient temperature of $9^{\circ} \mathrm{C}$ and a salinity of 30 ppt. Forty mussels were then transferred to each of eight 38-L tanks with filtered, running seawater. Mussels in two duplicate tanks served as the untreated controls receiving only supplemental algal food; mussels in another two tanks served as vehicle controls receiving algal food and microencapsulated corn oil. Mussels in the remaining tanks served as experimental treatments receiving algal food and either microencapsulated PAHs or PCBs. Duplicates for the experimental treatments were run simultaneously. The seawater flow in all tanks was maintained at $800-1000 \mathrm{~mL} \mathrm{min-1}$ (temperature $9.0 \pm 0.5^{\circ} \mathrm{C}$; salinity $30.0 \pm 0.5 \mathrm{ppt}$, and dissolved oxygen $>90 \%$ saturation). Mussels were fed daily with a commercially available concentrated and preserved algal diet consisting of Thalassiosira pseudonana (Coast Oyster Co., Quilcene, WA). The feeding rate in all tanks was adjusted to approximately $4 \times 10^{3}$ cells $\mathrm{mL}^{-1}$.

$\mathrm{J}$ ust before adding the microencapsulated contaminants, seawater flow was shut off in all the tanks. Seawater flow was restarted after $2 \mathrm{~h}$. Our observations revealed that mussels filtered all the encapsulated particles within 1-2 h. Constant and gentle aeration was maintained in all the tanks to keep the microencapsulated contaminants and algae in suspension. After 30 days, mussels from each treatment of the short-term exposure were randomly sampled from each duplicate tank for hemocytological $(n=20)$ and histological $(n=10)$ examination. Mussels undergoing longterm exposures were randomly sampled from each duplicate tank after $0(n=25), 90(n=30)$, and 180 days $(n=43-48$ ) from each of the treatments for hemocytological examination. Samples consisting of 15-20 mussels from the short-term exposure study at the 30-day period and from the long-term exposure study at 0,90 , and 180 days for each treatment group were also taken for chemical analysis, as described below. 


\section{Tissue Chemistry}

The analysis of body burden of tissue contaminants of mussels sampled from nonurban and urban sites of Puget Sound has already been described (Krishnakumar et al., 1994). For these analyses, whole mussel tissue samples ( $n=30 /$ site) were dissected out, pooled, and kept at $-20^{\circ} \mathrm{C}$ until analysis. For the laboratory exposures, whole mussel tissue samples $(n=15-20)$ were dissected, pooled, and kept at $-20^{\circ} \mathrm{C}$ until analysis. Samples were analyzed for organic chemical contaminants as described by Krahn et al. (1988) and Sloan et al. (1993). Concentrations of organic chemicals in the samples from long-term exposure were analyzed using a validated screening technique utilizing highpressure liquid chromotography (HPLC) (Krahn et al., 1993, 1994). Toxic and essential elements in tissues from the field studies were determined as described in Robisch and Clark (1993). Concentrations of organic contaminants and toxic metals were expressed in ng $\mathrm{g}^{-1}$ and $\mathrm{mg} \mathrm{g}^{-1}$ dry tissue weight, respectively.

\section{Histology}

Mussels were randomly selected and the digestive gland excised, cut transversely into two pieces, and fixed in Baker's formol-calcium. Tissue blocks were processed by a routine paraffin histology method. Sections $(5 \mu \mathrm{m})$ were stained with hematoxylin and eosin (H\&E) and examined microscopically for histological evidence of the disease, as described earlier (Mix, 1983).

\section{Hemocytol ogy}

A 22-gauge needle containing $0.5 \mathrm{~mL}$ of Tris-EDTA buffer was inserted between the valves and into the posterior adductor muscle to withdraw 0.2-0.5 mL of hemolymph. This hemolymph sample was placed on a poly-L-lysine-coated slide and incubated for $30 \mathrm{~min}$ in a moist chamber. After incubation, the slides were fixed in methanol and stained using the Schiff-Feulgen picromethyl blue procedure (Farley, 1969). Slides were then microscopically examined for the presence or the absence of HN, as described by Elston et al. (1988).

\section{Statistical Analysis}

Linear regression analysis was used to evaluate the relationship between the prevalence of $\mathrm{HN}$ and body burden of chemical contaminants in field sampled mussels. Contingency tables coupled with $\chi^{2}$ analysis was used to evaluate the devel opment of $\mathrm{HN}$ in mussels after either a short-term (30-day) or long-term (180day) exposure to PAHs and PCBs. Findings were considered significant at $\alpha=0.05$.

\section{RESULTS}

\section{Field Studies}

The concentrations of selected organic contaminants as well as toxic and essential elements in the whole tissue of mussel from the nine sites in Puget Sound are shown in Table 1. A more detailed description of the concentrations of organic and metal contaminants in mussel tissues from thesesites is presented in Krishnakumar et al. (1994). Tissue concentrations of total PAHs (e.g., fluoranthene, phenanthrene, benzo[a]pyrene), PCBs, DDTs, other pesticides, and selected metals (mercury and lead) were higher in mussels from the urban sites of Eagle Harbor, City Waterway, Seacrest, Four Mile Rock, and Sinclair Inlet than in those from nonurban sites (Oak Bay, Saltwater Park, Coupeville, and Double Bluff).

The percentage of prevalence of $\mathrm{HN}$ in natural populations of mussels from the nonurban and urban sites is summarized in Table2. Both histological and hemocytological examinations revealed that the mussel population from Double Bluff was disease free. A disease prevalence ranging from 0 to $30 \%$ in mussels from the nonurban sites and from 10 to $28 \%$ in mussels from the urban sites was observed. There was no significant relationship between tissue burden for any of the chemical contaminants measured and $\mathrm{HN}$ in mussels from natural populations from nonurban and urban sites in Puget Sound, WA (Table 3, Fig. 2).

Short-term experimental exposure In a study to validate the links between exposure to PAHs and PCBs and cytological damage identified in mussel populations from urban sites in Puget Sound (see Krishnakumar et al., 1994, 1995), HN-free mussels were exposed for 30 days to microencapsulated PAHs or PCBs (Krishnakumar et al., 1997). The relationship between $\mathrm{HN}$ and chemical contaminants was not the initial purpose of the study described in Krishnakumar et al. (1997). However, at the end of the exposure period, a large proportion of mussels exhibited $\mathrm{HN}$ as well as cytological damage. The relationship between chemical contaminant exposure and the prevalence of $\mathrm{HN}$ is what is currently being presented.

The tissue burdens of PAHs and PCBs in mussels after 30 days of exposure to mi croencapsulated contaminants are shown in Table 4. After 30 days of exposure to $\mathrm{PAHs}$, tissue concentrations of phenanthrene, fluoranthene, and benzo[a]pyrene increased by 400,360 , and 940 times, respectively, compared to vehicle control mussels. Similarly, after 30 days of exposure, tissue concentrations of Aroclor 1254 increased by 16 times compared with vehicle control mussels. Tissue burdens of the above contaminants in vehicle control mussels were comparable to tissue burdens in mussels fed only an algal diet (Table 4). 
TABLE 1

Concentration of Organic ( $\left.\mathrm{ng} \mathrm{g}^{-1}\right)$ and M etal $\left(\mathrm{mg} \mathrm{g}^{-1}\right)$ Contaminants in Whole Tissue (Dry Weight) of Mytilus edul is Collected from Puget Sound, Washington, during September 21-24, 1992

\begin{tabular}{|c|c|c|c|c|c|c|c|c|c|}
\hline \multirow[b]{2}{*}{ Contaminants } & \multicolumn{9}{|c|}{ Sites } \\
\hline & $\begin{array}{l}\text { Eagle } \\
\text { Harbor }\end{array}$ & $\begin{array}{c}\text { Commencement } \\
\text { Bay }\end{array}$ & Seacrest & $\begin{array}{l}\text { Four } \\
\text { Mile } \\
\text { Rock }\end{array}$ & $\begin{array}{l}\text { Sinclair } \\
\text { Inlet }\end{array}$ & $\begin{array}{l}\text { Oak } \\
\text { Bay }\end{array}$ & $\begin{array}{l}\text { Saltwater } \\
\text { Park }\end{array}$ & Coupeville & $\begin{array}{l}\text { Double } \\
\text { Bluff }\end{array}$ \\
\hline \multicolumn{10}{|l|}{$\begin{array}{l}\text { Polycyclic aro- } \\
\text { matic } \\
\text { hydrocar- } \\
\text { bons }\end{array}$} \\
\hline $\begin{array}{l}\text { Phenan- } \\
\text { threne }\end{array}$ & 9,000 & 330 & 110 & 150 & 24 & 14 & 17 & 20 & 15 \\
\hline Fluoranthene & 15,000 & 2000 & 510 & 360 & 49 & 17 & 37 & 20 & 23 \\
\hline $\begin{array}{l}\text { Benzo[a]py- } \\
\text { rene } \\
\text { Total HMW }\end{array}$ & 640 & 50 & 16 & 11 & 3 & 1 & 1 & 1 & 1 \\
\hline $\begin{array}{c}\mathrm{PAHs}^{\mathrm{a}} \\
\text { Chlorinated } \\
\text { hydrocar- } \\
\text { bons }\end{array}$ & 64,000 & 5800 & 1600 & 1140 & 220 & 110 & 170 & 130 & 120 \\
\hline $\begin{array}{l}\text { Polychlori- } \\
\text { nated }\end{array}$ & & & & & & & & & \\
\hline biphenylsb & 400 & 490 & 500 & 290 & 180 & 60 & 140 & 50 & 50 \\
\hline Total DDTsc & 21 & 29 & 28 & 19 & 15 & 11 & 9 & 11 & 11 \\
\hline $\begin{array}{l}\text { Other pesti- } \\
\text { cides }^{d} \\
\text { Metals }\end{array}$ & 16 & 33 & 22 & 17 & 11 & 10 & 17 & 12 & 11 \\
\hline $\begin{array}{l}\text { Metals } \\
\text { Arsenic }\end{array}$ & 3.0 & 3.6 & 3.3 & 3.7 & 2.7 & 5.4 & 3.1 & 3.2 & 3.2 \\
\hline Cadmium & 3.5 & 4.3 & 5.3 & 4.6 & 2.8 & 5.2 & 3.8 & 3.5 & 2.6 \\
\hline Mercury & 0.64 & 0.23 & 0.66 & 0.13 & 0.20 & 0.19 & 0.39 & 0.05 & 0.37 \\
\hline Lead & 0.94 & 12.0 & 1.4 & 1.5 & 0.95 & 0.55 & 0.55 & 0.86 & 0.41 \\
\hline
\end{tabular}

a $\Sigma$ Molecular weight PAHs includes the summed concentrations for the following organic compounds: naphthalene, acenaphthylene, acenapthene, fluorene, phenanthrene, anthracene, and 2-methylnaphthalene, fluoranthene, pyrene, benz[a]anthracene, chrysene, benzofluoranthenes, benzo[a]pyrene, indeno[1,2,3,-c,d]pyrene, dibenzo[a,h]anthracene, and benzo[g,h,i,]perylene.

b Poychlorinated biphenyls measured as Aroclor 1254.

c Total DDTs include the summed concentrations of the following compounds: DDT, DDE, and DDD.

d Pesticides include the summed concentrations of the following compounds: aldrin, chlordane, dieldrin, heptachlor, and lindane.

TABLE 2

The Prevalence of Hemic Neoplasia in Natural Populations of M. edulis Complex from Sites in Puget Sound, Washington

\begin{tabular}{|c|c|c|c|c|}
\hline \multirow[b]{2}{*}{ Site } & \multicolumn{2}{|c|}{ Histology } & \multicolumn{2}{|c|}{ Hemocytology } \\
\hline & $\mathrm{n}$ & $\begin{array}{c}\% \\
\text { Prevalence }\end{array}$ & $\mathrm{n}$ & $\begin{array}{c}\% \\
\text { Prevalence }\end{array}$ \\
\hline \multicolumn{5}{|l|}{ Nonurban } \\
\hline Oak Bay & 10 & 30 & 25 & 28 \\
\hline Saltwater Park & 10 & 20 & 30 & 16 \\
\hline Coupeville & 10 & 10 & 30 & 30 \\
\hline Double Bluff & 10 & 0 & 30 & 0 \\
\hline \multicolumn{5}{|l|}{ Urban } \\
\hline Eagle Harbor & 10 & 30 & 25 & 28 \\
\hline Commencement Bay & 10 & 30 & 30 & 10 \\
\hline Seacrest & 10 & 10 & 28 & 18 \\
\hline Four Mile Rock & 10 & 20 & 30 & 20 \\
\hline Sinclair Inlet & 10 & 0 & 30 & 13 \\
\hline
\end{tabular}

The prevalence of $\mathrm{HN}$ in mussels exposed for 30 days to $150 \mu \mathrm{g} \mathrm{L}^{-1}$ day $^{-1}$ of PAHs or PCBs, respectively, determined through histological and hemocytological examination is shown in Fig. 3. Histological examination revealed disease prevalences of 20 and $30 \%$ in the mussels exposed to model mixtures of PAHs and Aroclor 1254, respectively, whereas mussels fed an algal diet (untreated controls) were found to be still disease free after 30 days. However, a disease prevalence of $20 \%$ was also observed in vehicle control mussels (Fig. 3). There was no significant difference in the prevalence of mussels exhibiting $\mathrm{HN}$ that were exposed to either PAHs or PCBs when compared to mussels treated with corn oil (vehicle control) or to mussels fed an algal diet only. Hemocytological examination showed the disease present only in mussels exposed to Aroclor 1254 (20\%); however, this prevalence was not significantly different than the prevalence observed in mussels treated with corn oil (vehicle control) or to mussels fed an algal diet only. In addition, no mortality of mussels was observed 


\section{TABLE 3}

Relationship between Body Burden of Selected Chemical Contaminants and the Prevalence of Hemic Neoplasia in Natural Populations of M. edulis Complex from Nine Sites in Puget Sound, Washington

\begin{tabular}{|c|c|c|c|c|}
\hline \multirow[b]{2}{*}{$\begin{array}{l}\text { Chemical } \\
\text { contaminant }\end{array}$} & \multicolumn{2}{|c|}{$\begin{array}{l}\text { Hemic neoplasia } \\
\text { (histology) }\end{array}$} & \multicolumn{2}{|c|}{$\begin{array}{l}\text { Hemic neoplasia } \\
\text { (hemocytology) }\end{array}$} \\
\hline & $\begin{array}{c}\text { Correlation } \\
\text { coefficient }\end{array}$ & $\begin{array}{c}\text { Significance } \\
\text { level }\end{array}$ & $\begin{array}{c}\text { Correlation } \\
\text { coefficient }\end{array}$ & $\begin{array}{c}\text { Significance } \\
\text { level }\end{array}$ \\
\hline$\Sigma \mathrm{PAHs}^{\mathrm{a}}$ & .446 & 0.229 & .357 & 0.346 \\
\hline PCBs ${ }^{b}$ & .362 & 0.338 & .032 & 0.936 \\
\hline DDTsc & 287 & 0.454 & .084 & 0.829 \\
\hline Other pesti- & & & & \\
\hline cides $^{d}$ & . 429 & 0.250 & .227 & 0.557 \\
\hline Arsenic & .534 & 0.139 & .330 & 0.386 \\
\hline Cadmium & .555 & 0.121 & .415 & 0.267 \\
\hline Mercury & . 077 & 0.843 & .085 & 0.828 \\
\hline Lead & .409 & 0.275 & 286 & 0.456 \\
\hline
\end{tabular}

Note. Reported values include the correlation coefficient and the significance level using linear regression analysis.

a $\Sigma$ Molecular weight PAHs includes the summed concentrations for the following organic compounds: naphthalene, acenaphthylene, acenapthene, fluorene, phenanthrene, anthracene, and 2-methylnaphthalene, fluoranthene, pyrene, benz[a]anthracene, chrysene, benzofluoranthenes, benzo[a]pyrene, indeno[1,2,3,-c,d]pyrene, dibenzo[a,h]anthracene, and benzo[g,h,i,]perylene.

b Poychlorinated biphenyls measured as Aroclor 1254.

c Total DDTs include the summed concentrations of the following compounds: DDT, DDE, and DDD.

d Pesticides include the summed concentrations of the following compounds: aldrin, chlordane, dieldrin, heptachlor, and lindane.

in any of the treatment groups throughout the experimental period.

Long-term experimental exposure Based on the re sults of short-term exposure to PAHs and PCBs, a long-term (180-day) exposure study was conducted to evaluate the influence of PAHs or PCBs in modulating

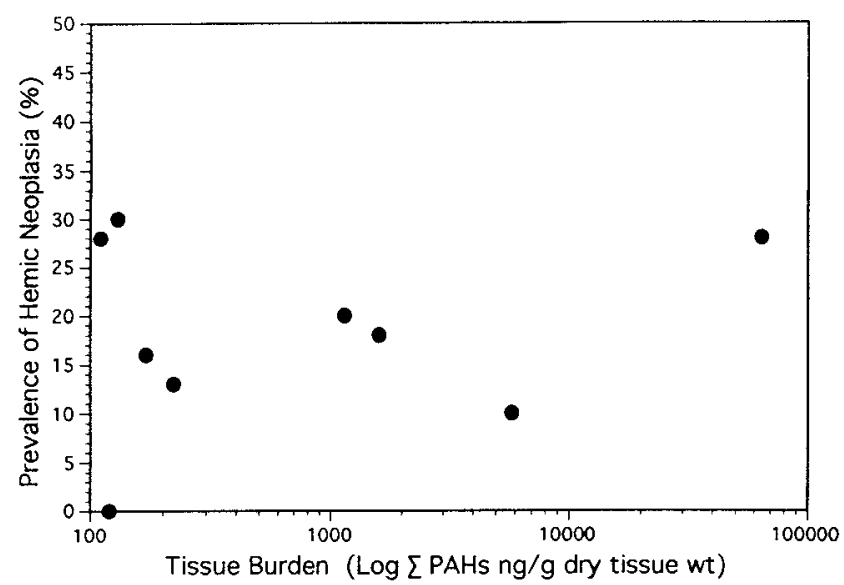

FIG. 2. The relationship between the prevalence of hemic neoplasia (leukemia) and tissue burden of PAHs in Mytilus edulis complex from Puget Sound.

\section{TABLE 4}

Concentration of Selected PAHs and PCBs in Whole Tissue of $\mathrm{M}$. edulis Complex (ng g ${ }^{-1}$ Dry Tissue Weight) after 30 Days of Exposure to Microencapsulated PAHs and PCBs (Arochlor 1254) at a Concentration of $150 \mathrm{\mu g} \mathrm{L}^{-1}$ Seawater

\begin{tabular}{lcccc}
\hline & \multicolumn{4}{c}{ Chemical contaminant } \\
\cline { 2 - 5 } Treatment & Phenanthrene Fluoranthene Benzo[a]pyrene PCBs \\
\hline Algae only & 58 & 150 & 6 & 400 \\
$\begin{array}{l}\text { Corn oil (vehicle } \\
\text { control) }\end{array}$ & 59 & 160 & 7 & 540 \\
PAHs & 24000 & 58000 & 6600 & - \\
PCBs & - & - & - & 8700 \\
\hline
\end{tabular}

the prevalence of $\mathrm{HN}$ in a mussel population already exhibiting a moderate HN prevalence. Tissue burdens of PAHs and PCBs in mussels after 90 and 180 days of exposure, respectively, to microencapsulated contaminants are shown in Table 5. Tissue concentrations of PAHs and PCBs in vehicle control and mussels fed only algae after 90 and 180 days were comparable to tissue concentrations of PAHs and PCBs in mussels at the start of the experiment. After 90 days of exposure to $\mathrm{PAHs}$, tissue concentrations of phenanthrene and benzo[a]pyrene equivalent compounds increased by 8 and 40 times, respectively, compared with vehicle control mussels. Similarly, after 180 days exposure to PAHs, tissue concentrations of phenanthrene and benzo[a]pyrene equivalent compounds increased by 28 and 50 times, respectively, compared with vehicle control mussels. Tissue concentrations of Arocl or 1254 after 90 and 180 days exposure increased by 500 and 175 times, respectively, compared with vehicle control mussels.

The prevalence of $\mathrm{HN}$ in mussels exposed for 90 and 180 days to $10 \mu \mathrm{g} \mathrm{L}^{-1}$ day $^{-1}$ of PAHs or PCBs, determined through hemocytol ogical examination, is summarized in Fig. 4. The initial disease prevalence in the field population of mussels used for long-term exposure

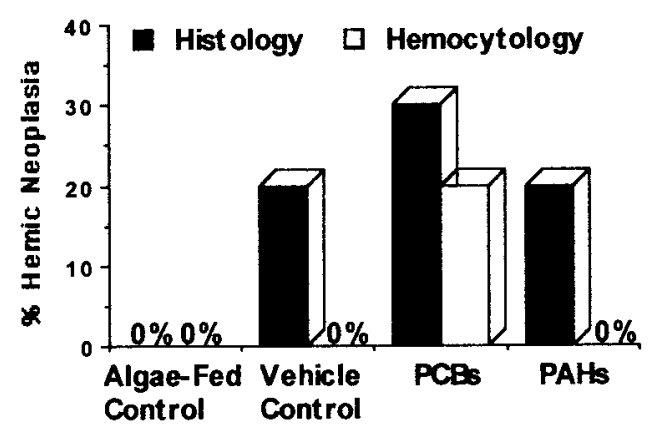

FIG. 3. The prevalence of hemic neoplasia (leukemia) in $\mathbf{M}$. edulis complex after a 30-day exposure to microencapsulated PAHs (fluoranthene, phenanthrene, and benzo[a]pyrene in a 5:4:1 ratio, respectively) and PCBs (Aroclor 1254) in the laboratory (150 $\mathrm{g} \mathrm{L}^{-1}$ day $\left.^{-1}\right)$. Determined using histological $(n=10)$ and hemocytological $(n=20)$ techniques. 


\section{TABLE 5}

Concentration of Selected PAHs (as ng Phenanthrene or Benzo[a]pyrene Equivalents/g Dry Tissue Weight) and PCBs (as Sum of Planar and Coplanar PCB Congeners, ng $\mathrm{g}^{-1}$ Dry Tissue Weight) in Whole Tissue of M. edulis Complex after 90 and 180 Days of Exposure to Microencapsulated PAHs and PCBs (Arochlor 1254) at Concentrations Equivalent to $10 \mu \mathrm{g}$ $\mathrm{L}^{-1}$ Seawater

\begin{tabular}{|c|c|c|c|}
\hline \multirow[b]{2}{*}{ Treatment } & \multicolumn{3}{|c|}{ Chemical contaminant } \\
\hline & $\begin{array}{c}\text { PAHs (ng } \\
\text { phenanthrene } \\
\text { eq } / \mathrm{g} \text { ) }\end{array}$ & $\begin{array}{c}\text { PAHs (ng } \\
\text { benzo[a]pyrene } \\
\text { eq } / \mathrm{g} \text { ) }\end{array}$ & $\begin{array}{c}\Sigma \text { PCB } \\
\text { congeners }\end{array}$ \\
\hline \multicolumn{4}{|l|}{ Day 0} \\
\hline $\begin{array}{l}\text { Algae only } \\
\text { (untreated } \\
\text { control) }\end{array}$ & 53 & 4 & 10 \\
\hline \multicolumn{4}{|l|}{ Day 90} \\
\hline $\begin{array}{l}\text { Algae only } \\
\text { (untreated } \\
\text { control) }\end{array}$ & 74 & 5 & 14 \\
\hline $\begin{array}{l}\text { Corn oil (vehicle } \\
\text { control) }\end{array}$ & 79 & 5 & 15 \\
\hline PAHs & 610 & 200 & - \\
\hline PCBs & - & - & 7600 \\
\hline Day 180 & & & \\
\hline $\begin{array}{l}\text { Algae only } \\
\text { (untreated } \\
\text { control) }\end{array}$ & 37 & 5 & 19 \\
\hline $\begin{array}{l}\text { Corn oil (vehicle } \\
\text { control) }\end{array}$ & 20 & 4 & 31 \\
\hline $\mathrm{PAHs}$ & 570 & 200 & - \\
\hline PCBs & - & - & 5400 \\
\hline
\end{tabular}

(0 time) was $20 \%$. After 90 days, disease prevalence increased to 33 and $43 \%$ in mussels exposed to PAHs and PCBs, respectively. The disease prevalence in mussels fed only an algal diet was $20 \%$, comparable to the disease prevalence of mussels at the start of the exposure, whereas in vehiclecontrol mussels, the prevalence of $\mathrm{HN}$ increased to $31 \%$. There was, however, no significant difference in the prevalence of $\mathrm{HN}$ among

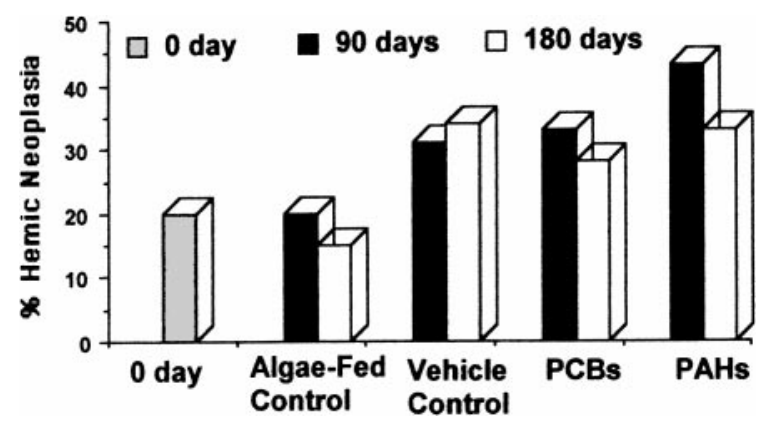

FIG. 4. The prevalence of hemic neoplasia (leukemia) in $M$. edulis complex determined by hemocytological techniques after 0 days $(n=25), 90$ days $(n=30)$ and 180 days $(n=43-48)$ exposure to microencapsulated PAHs (fluoranthene, phenanthrene, and benzo[a]pyrene in a 5:4:1 ratio, respectively) and PCBs (Aroclor 1254) in the laboratory $\left(10 \mathrm{\mu g} \mathrm{L}^{-1}\right.$ day $\left.^{-1}\right)$. the treatments at this time period. After 180 days, increased disease prevalences of 34, 28, and 33\% were observed in vehicle control mussels and in mussels exposed to PAHs and PCBs, respectively, compared to an $\mathrm{HN}$ prevalence of $15 \%$ in mussels fed only an algal diet. There was no significant difference in the prevalence of mussels exhibiting $\mathrm{HN}$ that were exposed to either PAHs or PCBs when compared to mussels treated with corn oil (vehicle control); however, the prevelence of $\mathrm{HN}$ in mussels treated with corn oil, PAHs, or PCBs was significantly higher than its prevalence in mussels fed an algal diet only. This is attributable, in part, to the larger sample size per treatment used at the end of the experimental period ( $n=55$ to 63 mussels) compared to thesamplesize used at themidpoint of theexperimental period ( $n=36$ to 43 mussels). Mortality of mussels was evident in the various treatment groups and ranged from 8 to $16 \%$ at the end of the experimental period, but was not significantly different among the treatment groups.

Morphology of neoplastic cells. Light microscopic examination of hemocytes from normal mussels reveal ed that they were well attached and spread on glass slides with relatively small uniform nuclei (Figs. 5a and $5 b)$. Frequently, cell clumps consisting of more than 25-35 hemocytes were observed. In contrast, neoplastic hemocytes routinely did not clump but remained rounded, with extremely limited spreading (Figs. 5c and 5d). Hemocytes of mussels from both the wild population and laboratory-exposed mussel s showed the presence of two types of neoplastic cells, as reported by earlier researchers (Lowe and Moore, 1978; Green and Alderman, 1983). The most common abnormal hemocytes were larger in size and contained a greatly enlarged spherical or lobed nucleus (Fig. 5d). The second type of abnormal hemocyte was relatively smaller in size and had a more or less spherical nucleus with multiple nucleoli (Fig. 5d). Mitotic figures were observed frequently in neoplastic hemocytes (Figs. 5c and $5 d$ ).

Histological examination of mussels with HN showed neoplastic hemocytes in the connective tissues between the digestive tubules of both the wild populations and laboratory-exposed mussels (Figs. 5f-5h). The progression of the disease was characterized by an increase in the number of neoplastic cells which, in advanced stages, completely filled the vascular connective tissue and vascular spaces throughout the digestive gland (Figs. 5g and 5h).

\section{DISCUSSION}

This study develops information about the possible relationship between the prevalence of $\mathrm{HN}$ in wild populations of $\mathrm{M}$. edulis collected from sites in Puget Sound, Washington, and body burden of environmental 

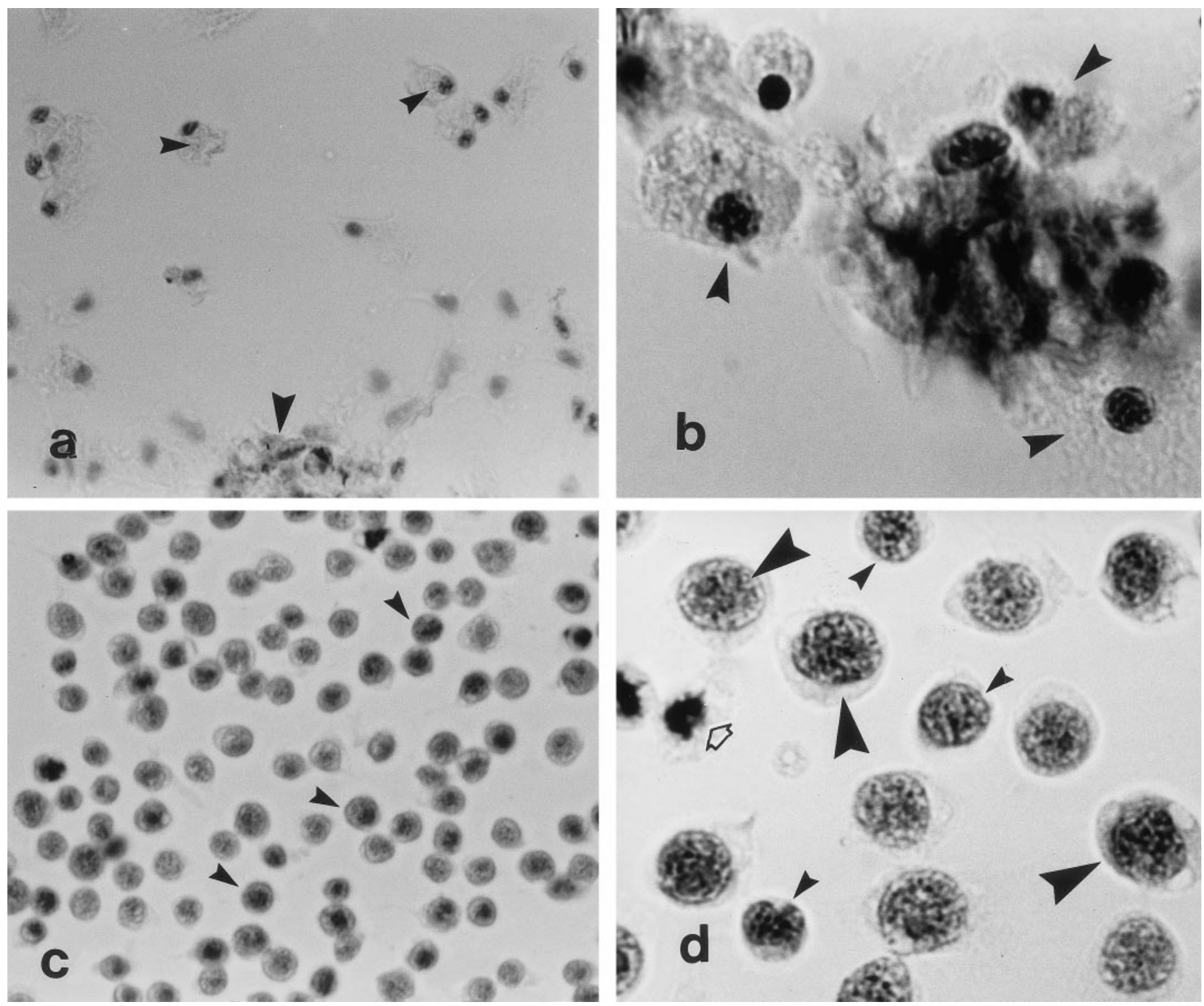

FIG. 5. (a) Hemocytological comparison of hemocytes (shown with small arrowheads) from a healthy mussel (M. edulis). Cell clumps are often seen (shown with large arrowhead) $(\times 400)$; (b) magnified view of normal hemocytes (shown with arrowheads) seen well attached and spread with relatively small uniform nuclei $(\times 1000)$; (c) neoplastic hemocytes, round and with extremely limited spreading (shown with arrowheads), sampled from a mussel in the advanced stage of the disease $(\times 400)$; (d) magnified view of neoplastic hemocytes with higher nuclear to cytoplasmic ratio and distinct nucl eolus. The most common neoplastic hemocytes (shown with large arrowheads) were larger in size and contained a greatly enlarged spherical or lobed nucleus. The second type of hemocyte (shown with small arrowhead) were relatively smaller in size and had a more or less sperical nucleus. Mitotic figures (shown by outline arrow) are frequently observed in neoplastic hemocytes (×1000); (e) histological section of digestive gland of 30-day algal control mussel showing normal hemocytes (shown with arrowheads) in the open circulatory system (×100); (f) neoplastic hemocytes (shown with arrowheads) from mussels exposed to PCBs for 30 days ( $\times 100)$; $(\mathrm{g})$ aggregation of neoplastic hemocytes (shown with arrowheads) in the open circulatory system of $30-$ day vehicle control mussel (×100); (h) hemocytes in the advanced stage of neoplastic progression (shown with arrowhead) in the open circulatory system of 30-day vehicle control mussel $(\times 200)$.

contaminants. Our field study showed no relationship between the prevalence of $\mathrm{HN}$ with body burdens of both organic and inorganic contaminants. F or example, the tissue concentrations of carcinogenic and other organic and toxic metal contaminants were found to be higher in mussels sampled from five urban sites. However, the prevalence of $\mathrm{HN}$ in mussels from the urban sites (13-28\%) was found to be in the same range as in mussels from the nonurban sites (0-30\%). I ncidentally, mussels having the highest and lowest tissue concentrations of benzo[a]pyrene, a known carcinogen, from Eagle Harbor and Oak Bay, respectively, showed the same levels of $\mathrm{HN}, 28-30 \%$. This is in contrast to findings reported by Mix et al. (1979), who showed a 

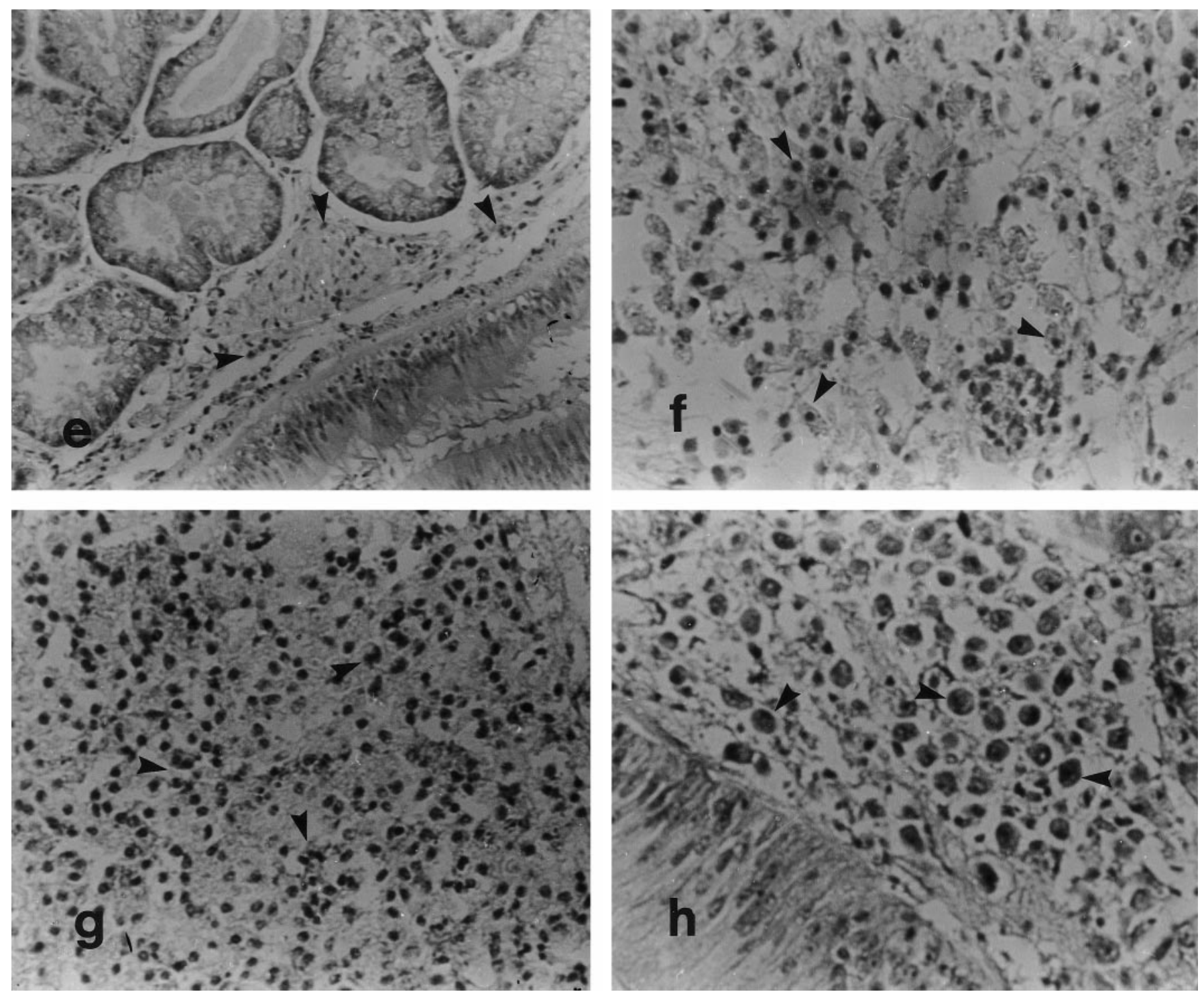

FIG. 5-Continued

positive relationship between benzo[a]pyrene body burden and the prevalence of $\mathrm{HN}$ in a $\mathrm{M}$. edulis population from Oregon.

Several authors have suggested that $\mathrm{HN}$ in bivalve molluscs is induced or promoted by anthropogenic or natural carcinogenic chemicals (Loweand M oore, 1978; McLaughin et al., 1992). Correlations were reported between the prevalence of $\mathrm{HN}$ in $\mathrm{M}$. edulis and $\mathrm{My}$. arenaria and tissue burdens of organic contaminants (Mix et al., 1979; Farley et al., 1991). In the present study, the body burden of PAHs ranged from less than 0.1 to $64 \mathrm{ppm}$ and PCBs ranged from 0.07 to $0.5 \mathrm{ppm}$. The range in body burden for toxic metals was not as great as it was for the organic contaminants, although lead concentrations in mussels from Commencment Bay were approximately an order of magnitude higher than those for other sites. Despite the wide range in concentration of organic and inorganic contaminants, no relationship between chemical contaminants and $\mathrm{HN}$ prevalence in natural populations was identified. This finding is supported in field investigations by several other researchers who failed to show evidence for a clear cause-and-effect relationship between environmental contaminants and the disease prevalence of HN in bivalves (Brown et al., 1979; Appeldoorn et al., 1984).

Although the field studies reveal ed no need to further investigate the relationship between $\mathrm{HN}$ and chemical contaminants, a laboratory study designed to evaluate the causal relationship between environmental contaminants and cytological structural damage in the digestive gland of mussels revealed development of $\mathrm{HN}$ in a 
population of mussels previously identified to be $\mathrm{HN}$ free. Few studies have examined the ability of known carcinogenic compounds to induce $\mathrm{HN}$ in marine bivalves under laboratory conditions (Rasmussen et al., 1983a,b, 1985). However, theexistence of various detoxifying enzymes and their ability to metabolize certain classes of chemicals to carcinogens in bivalve molluscs (see review by Livingstone, 1991) has been documented, supporting the possi bility that carcinogenic compounds could induce the development of neoplasia in bivalves. In the present study, when healthy mussels were exposed for 30 days to PAHs and PCBs, the prevalence of $\mathrm{HN}$ increased 20 to $30 \%$. H owever, the same increase in $\mathrm{HN}$ prevalence was also observed in mussels exposed to corn oil (vehicle) alone; therefore, it appeared unlikely that the development of $\mathrm{HN}$ was related to exposure to chemical contaminants.

There appeared to be a difference in the prevalence of $\mathrm{HN}$, depending on the method of diagnosis (see Fig. 3). Several researchers have reported that the histological and hemocytological assessments of $\mathrm{HN}$ in bivalves were comparable, even though the histological diagnosis represents the recommended standard method. In the short-term exposure portion of the study using healthy mussels, we primarily observed early stages of disease progression where many if not all disseminated neoplasms are characterized by foci of neoplastic cells and/or raresingle cells in variable locations throughout the open circulatory system. In such cases, hemocytologic examinations may fail to accurately diagnose the prevalence of $\mathrm{HN}$, whereas histologic examination can provide qualitative detection of such cells. In our short-term study, HN was identified histologically in mussels receiving corn oil, PAHs, or PCBs, whereas HN was only identified hemocytol ogi cally in mussels receiving PCBs only. The discrepancy may in part be a result of the lack of sensitivity of the hemocytological approach in identifying $\mathrm{HN}$ in our samples for the reasons described above. For large-scale population surveys, however, the practice of applying the histologic technique employing paraffin sectioning and staining represents a laborious and time-consuming practice in comparison with hemocytological techniques in identifying $\mathrm{HN}$ in bivalves. Therefore, when high sensitivity is desired, both hemocytologic and histologic techniques should be used (EIston et al., 1992) to assess HN and the results viewed in total. In our study, we employed the histologic techniques in a very limited way; to confirm our findings. We also improved the accuracy of the hemocytologic technique by increasing the sample number (40-50 per exposure), which was the primary assessment tool used in the long-term exposure study.

Because of the unexpected development of $\mathrm{HN}$ in the initial laboratory exposure, a second longer term exposure to PAHs and PCBs was conducted using a population of mussels which already harbored $\mathrm{HN}$ in the population. The expectation was that in this group, increased $\mathrm{HN}$ induced by chemical contaminants might be potentiated by corn oil. A key element of this disease is the widely demonstrated capacity for horizontal transmission in every species studied (including $\mathrm{M}$. edulis complex from Puget Sound); neoplasm-free bivalves readily acquire the disease by cohabitation with affected conspecifics or injection with intact neoplastic cells (Elston et al., 1992). However, even under the condition of long-term exposure for 180 days to PAHs and PCBs, an increase in the prevalence of $\mathrm{HN}$ was observed in all groups receiving corn oil. The additional temporal exposure to PAHs or PCBs did not increase the development of $\mathrm{HN}$ in bivalves above the level observed in mussels receiving corn oil alone.

It is reported that other stressors can increase the prevalence and quite probably the rate of progression of $\mathrm{HN}$ if the disease is already present in bivalve populations (Elston et al., 1992). For example, in M. edul is and My. arenaria increased prevalence of disease was reported during cooler months of the year (Elston et al., 1992). Chemical contaminants have al so been reported to influence the development of $\mathrm{HN}$ as well. For example, Khudoley and Syrenko (1978) reported the experimental induction of neoplasia in freshwater bivalves exposed to the aromatic amines. In contrast, Rasmussen et al. (1983a,b) reported failure to induce $\mathrm{HN}$ in $\mathrm{M}$. edul is receiving repeated experimental injections of aromatic amines, such as dimethylnitrosamine and $\mathrm{N}$-methyl-N-nitronitrosoguanidine. Based on our results, there appears to be a discrepancy in the influence of stress in mitigating the devel opment of $\mathrm{HN}$ in bivalves, a discrepancy that may be stress specific. Certain biotic and/or abiotic factors can possibly favor $\mathrm{HN}$ in bivalves, acting as additional stresses that weaken the host defense. For example, after 30 days, a disease prevalence of $20 \%$ was observed in healthy mussels exposed to corn oil (vehicle). In fact, histological examination revealed advanced stages of $\mathrm{HN}$ in mussels exposed to corn oil. Similarly, after long-term exposure to corn oil the prevalence of $\mathrm{HN}$ also increased. No study has previously reported on the carcinogenicity of corn oil to mussels or other bivalves. In a related study, using tissue samples from short-termexposed mussels, severe pathological changes were observed at cellular and subcellular levels in the digestive cells of mussels exposed for 6 and 30 days to corn oil (Krishnakumar et al., 1997). Although chemical contaminants of concern did not influence the devel opment of $\mathrm{HN}$ in the blue mussel, the ability of other outside agents to affect the development of $\mathrm{HN}$ and the mechanisms which potentiate these actions should be further explored.

In conclusion, we failed to find any relationship between the prevalence of $\mathrm{HN}$ and body burden of environmental contaminants in M. edulis complex col- 
lected from nine sites in Puget Sound. Moreover, exposure to microencapsulated PAHs or Aroclor 1254 for 30 to 180 days did not alter the prevalence of $\mathrm{HN}$ in mussels. Overall, chemical contaminants do not appear to be directly involved in altering the prevalence of $\mathrm{HN}$ in the mussel ( $M$. edul is complex). F eeding microencapsulated corn oil to mussels, however, appears to alter (increase) the prevalence of $\mathrm{HN}$, although the mechanism remains unclear. Although chemical contaminants, under the current conditions, did not appear to be involved in altering $\mathrm{HN}$ prevalence, further longterm experimental studies, in the presence and the absence of various cocarcinogens and promoters, could be conducted to evaluate possible interactive causal relationships between selected environmental contaminants and the prevalence of $\mathrm{HN}$ in bivalve molluscs.

\section{ACKNOWLEDGMENTS}

P.K.K. is thankful to the Department of Biotechnology, Government of India, New Delhi, for awarding a Biotechnology Overseas Associateship for conducting this study. The authors are thankful to Dr. R. A. Elston, Batelle Marine Science Laboratory, Sequim, Washington, for his helpful discussions and valuable suggestions for conducting this study. The authors also thank the fol lowing members of the Environmental Conservation Division: Dave Misitano and Steve Eddy for help in sample collection and the experimental exposure study; Paul Olson for tissue processing and preparing histological slides; Dr. Sin Lam-Chan, Don Brown, and Dr. Jim Meador for overseeing timely completion and quality control of chemical analysis of mussel tissue samples; and Gina Ylitalo, Larry Hufnagel, Nick Adams, and Daryl Boyd for conducting the chemical analyses of tissue samples.

\section{REFERENCES}

Appeldoorn, R. S., Brown, C. W., Brown, R. S., Chang, P. W., Cooper, K. R., Lorda, E., Salia, S., Walker, H., and Wolke, R. E. 1984. "Field and Laboratory Studies to Definethe Occurence of Neoplasia in the Soft Shell Clam Mya arenaria.." Am. Petroleum Inst. Publication 4345, Washington, DC.

Balouet, G., Poder, M., Cahour, A., and Auffret, M. 1986. Proliferative hemocytic condition in European flat oysters (Ostrea edulis) from Breton Coasts: A 6-year survey. J . I nvertebr. Pathol . 48, 208-215.

Barry, M., and Yevich, P. P. 1975. The ecological, chemical and histopathological evaluation of an oil spill site. III. Histopathological studies. Mar. Pollut. Bull. 6, 171-173.

Brown, R. S., Wolke, R. E., Brown, C. W., and Saila, S. B. 1979. Hydrocarbon pollution and the prevalence of neoplasia in New England soft shell clams (Mya arenaria). In "Animals as Monitors of Environmental Pollutants," pp. 41-51. Nat. Res. Council, Nat. Acad. Press, Washington, DC.

Couch, J. A., and Harshbarger, J . C. 1985. Effects of carcinogenic agents on aquatic animals: An environmental overview. Environ. Carcinog. Rev. 3, 63-105.

Elston, R. A., Moore, J. D., and Brooks, K. 1992. Disseminated neoplasia of bivalve molluscs. Rev. Aquat. Sci. 6, 405- 466.

Elston, R. A., Kent, M. L., and Drum, A. S. 1988. Progression, lethality and remission of hemic neoplasia in the bay mussel Mytilus edulis. Dis. Aquat. Org. 4, 135- 142.

Farley, C. A. 1969. Probable neoplastic disease of the hematopoietic system in oysters, Crassostrea virginica and Crassostrea gigas. N atl. Cancer I nst. Monogr. 31, 541-555.
Farley, C. A., Plutschak, D. L., and Scott, R. F. 1991. Epizootiology and distribution of transmissible sarcoma in Maryland softshell clams, Mya arenaria 1984-1988. Environ. Health Perspect. 90, 35-41.

Green, M., and Alderman, D. J. 1983. Neoplasia in Mytilus edulis from United Kingdom waters. Aquaculture 30, 1-10.

Khudoley, V. V., and Syrenko, O. A. 1978. Tumor induction by $\mathrm{N}$-nitroso compounds in bivalve mollusks Unio pictorum. Cancer Lett. 4, 349-354.

Krahn, M. M., Moore, L. K., Bogar, R. G., Wigrens, C. A., Chan, S.-L., and Brown, D. W. 1988. High performance liquid chromatographic methods for isolating organic contaminants from tissue and sediment extracts. J . Chromatogr. 437, 161-175.

Krahn, M. M., Ylitalo, G. M., Burzitis, J ., Chan, S-L., and Varanasi, U. 1993. Rapid high-performance liquid chromatographic methods that screen for aromatic compounds in environmental samples. J . Chromatogr. 642, 15-32.

Krahn, M. M., Ylitalo, G. M., Burzitis, J ., Sloan, C. A., Boyd, D. T., Chan, S.-L., and Varanasi, U. 1994. Screening for planar chlorobiphenyl congeners in tissues of marine biota by high-performance liquid chromatography with photodiode array detection. Chemosphere29, 117-139.

Krishnakumar, P. K., Casillas, E., and Varanasi, U. 1994. Effect of environmental contaminants on the health of Mytilus edulis from Puget Sound, Washington, USA. I. Cytochemical measures of Iysosomal responses in the digestive cells using automatic image analysis. Mar. Ecol. Prog. Ser. 106, 249-261.

Krishnakumar, P. K., Casillas, E., and Varanasi, U. 1995. Effects of environmental contaminants on the health of Mytilus edulis from Puget sound, Washington, USA. II. Cytochemical detection of subcellular changes in the digestive cells. Mar. Biol. 124, 251-259.

Krishnakumar, P. K., Casillas, E., and Varanasi, U. 1997. Cytochemical responses in the digestive cells of Mytilus edulis complex exposed to microencapsulated PAHs or PCBs. Comp. Biochem. Physiol. C. 118C, 11-18.

Livingstone, D. R. 1991. Organic xenobiotics metabolism in marine invertebrates. In "Advances in Comparative and Environmental Physiology" (R. Gilles, Ed.), pp. 45-185, Springer-Verlag, Berlin.

Lowe, D. M., and Moore, M. N. 1978. Cytology and quantitative cytochemistry of a proliferative atypical hemocytic condition in Mytilus edulis (Bivalvia, Mollusca). J . Natl. Cancer Inst. 60, 1455-1459.

McLaughlin, S. M., Farley, C. A., and Hetrick, F. M. 1992. Transmission studies of sarcoma in the soft-shell clam, Mya arenaria. In Vivo 6, 367-370.

Mix, M. C. 1983. Hemic neoplasm of bay mussels Mytilus edulis from Oregon: Occurence, prevalence, seasonality and histological progression. J . Fish. Dis. 6, 239-248.

Mix, M. C., and Schaffer, R. L. 1983. Concentration of unsubstituted polynuclear aromatic hydrocarbons in bay mussels (Mytilus edulis) from Oregon, USA. Mar. Environ. Res. 9, 193-209.

Mix, M. C., Trenholm, S. R., and King, K. T. 1979. Benzo[a]pyrene body burdens and the prevalence of proliferative disorders in mussels (Mytilus edulis) in Oregon. In "Animals as Monitors of Environmental Pollution," pp. 52-62. Nat. Acad. of Sci., Washington, DC.

Moore, J . D., Elston, R. A., Drum, A. S., and Wilkinson, M. T. 1991. Alternate pathogenesis of systemic neoplasia in the bivalve mollusc Mytilus. J . Invertebr. Pathol . 58, 231-243.

Oprandy, J . J ., Chang, P. W., Pronovost, A. D., Cooper, K. R., Brown, R. S., and Yates, V. J. 1981. Isolation of a viral agent causing hematopoietic neoplasia in the soft shell clam Mya arenaria. J . Invertebr. Pathol. 38, 45-51.

Rasmussen, L. P. D. 1986. Occurrence, prevalence and seasonality of 
neoplasia in the marine mussel Mytilus edulis from three sites in Denmark. Mar. Biol. 92, 59-64.

Rasmussen, L. P. D., Hage, E., and Karlog, O. 1983a. Light and electron microscopic studies of the acute and chronic toxic effects of $\mathrm{N}$-Nitroso compounds on the marine mussel, Mytilus edulis (L). I. N-nitrosodimethylamine. Aquat. Toxicol . 3, 285-299.

Rasmussen, L. P. D., Hage, E., and Karlog, O. 1983b. Light and electron microscopic studies of the acute and chronic toxic effects of $\mathrm{N}$-nitroso compounds on the marine mussel, Mytilus edulis (L.). II . $\mathrm{N}$-methyl-N-nitro-N-nitrosoquanidine. Aquat. Toxicol. 3, 301-311.

Rasmussen, L. P. D., Hage, E., and Karlog, O. 1985. Light and electronmicroscopic studies of the acute and long-term toxic effects of $\mathrm{N}$-nitrosodipropylamine and $\mathrm{N}$-methylnitrosurea on the marine mussel Mytilus edulis. Mar. Biol. 85, 55-65.

Robisch, P. A., and Clark, R. C. 1993. Sample preparation and analyses of trace metals by atomic absorption spectroscopy. In "Sampling and Analytical Methods of the National Status and Trends Program-National Benthic Surveillance Program and Mussel Watch Project 1984-1992" (G. G. Lauenstein and A. Y. Cantillo, Eds.), Vol. III. pp. 111-150. Comprehensive description of elemental analytical methods. NOAA Tech. Memo NOS ORCA 71.
Sloan, C. A., Adams, N. G., Pearce, R. W., Brown, D. W., and Chan, S.-L. 1993. Northwest Fisheries Science Center analytical procedures. In "Sampling and analytical methods of the National Status and Trends Program-National Benthic Surveillance and Mussel Watch Projects 1984-1992 (G. G. Lauenstein and A. Y. Cantillo, Eds.)," Vol. IV, pp. 53-97. Comprehensive descriptions of trace organic analytical methods. NOAA Tech. Memo NOS/ORCA 71.

Stromgren, T., Nielsen, M. V., and U eland, K. 1986. Short term effects of microencapsulated hydrocarbons on shell growth of Mytilus edulis. Mar. Biol. 91, 33-39.

White, M. K., Miosky, D., Flessas, D. A., and Reinisch, C. L. 1993. The expression of an adhension-related protein by clam hemocytes. J . Invertebr. Pathol . 61, 253-259.

Winstead, J. T., and Couch, J. A. 1988. Enhancement of protozoan pathogen (Perkinsus marinus) infections in American oysters, Crassostrea virginica, exposed to the chemical carcinogen $\mathrm{N}$ nitrosodiethylamine (DENA). Dis. Aquat. Org. 5, 205-213.

Yevich, P. P., and Barszcz, C. A. 1977. Neoplasia in soft shell clams (Mya arenaria) collected from oil impacted sites. Ann. N.Y. Acad. Sci. 298, 409-426. 